\title{
Successful creation of an anemia management algorithm for hemodialysis patients
}

This article was published in the following Dove Press journal: International Journal of Nephrology and Renovascular Disease 23 June 2015

Number of times this article has been viewed

\section{Kazuhiro Hara \\ Yasuhide Mizutani \\ Hitoshi Kodera \\ Masato Miyake \\ Yoshiki Yasuda \\ Sanae Ohara}

Department of Nephrology, Yokkaichi Social Insurance Hospital, Yokkaichi, Mie Prefecture, Japan
Correspondence: Kazuhiro Hara Department of Nephrology, Yokkaichi Social Insurance Hospital, 10-8, Hazuyama-chou, Yokkaichi, Mie Prefecture, 5I0-0016, Japan

$\mathrm{Tel}+8|5933| 2000$

Fax +8I 593310354 Email yokkaichialgorithm@ba2.so-net. ne.jp
Introduction: Several anemia guidelines for hemodialysis patients have recommended a target hemoglobin $(\mathrm{Hb})$ range of 10-12 g/dL. However, maintaining Hb values continuously within a narrow target has been difficult, and there has been no generally accepted anemia management algorithm for hemodialysis patients.

Methods: In our study, we created an anemia management algorithm that considers the length of erythrocyte lifetimes, focuses on the combination of erythropoiesis-stimulating agent management and iron administration, and prevents iron deficiency and overload. Our algorithm established a target $\mathrm{Hb}$ range of 10-12 g/dL.

Results: We evaluated our algorithm in 49 patients for 6 months. The mean $\mathrm{Hb}$ values were approximately $11 \mathrm{~g} / \mathrm{dL}$ during our study period. The percentage of patients in the target $\mathrm{Hb}$ range of $10-12 \mathrm{~g} / \mathrm{dL}$ increased from $77.6 \%$ (38 of 49) at baseline to $85.7 \%$ (42 of 49) at 4-6 months. Throughout monthly regular blood tests during 1-6 months after we introduced our algorithm, $\mathrm{Hb}$ values remained within the target range in $55.1 \%$ (27 of 49$)$ of patients. The standard deviation of $\mathrm{Hb}$ values significantly decreased at 5 and 6 months ( $P=0.013$ and $P=0.047$, respectively; $1 \mathrm{~g} / \mathrm{dL}$ at 0 month, $0.7 \mathrm{~g} / \mathrm{dL}$ at 5 months, and $0.7 \mathrm{~g} / \mathrm{dL}$ at 6 months). Our algorithm also succeeded in suppressing cumulative doses of iron $(\leq 800 \mathrm{mg})$ and decreasing the ferritin values significantly $(P=0.011)$. There were no significant differences in erythropoiesis-stimulating agent doses between 0 and 6 months $(P=0.357)$.

Conclusion: Our anemia management algorithm successfully increased the number of patients in the target $\mathrm{Hb}$ range, significantly decreased the $\mathrm{Hb}$ standard deviation, suppressed cumulative doses of iron, and decreased ferritin values. These results suggest a better prognosis for hemodialysis patients. Further studies are required to evaluate our algorithm.

Keywords: erythropoiesis-stimulating agent, hemoglobin, iron, hemoglobin standard deviation, target hemoglobin range, ferritin

\section{Introduction}

The use of erythropoiesis-stimulating agents (ESAs) and iron administration have enabled anemia control in hemodialysis patients without blood transfusions. ${ }^{1-3}$ However, hemoglobin $(\mathrm{Hb})$ values that are too high or too low can worsen the prognosis. ${ }^{4-8}$ The European Renal Best Practice position statement recommends a target $\mathrm{Hb}$ range of 10-12 g/dL. ${ }^{9}$ Similarly, the Japanese Society for Dialysis Therapy recommends a target $\mathrm{Hb}$ range of $10-11 \mathrm{~g} / \mathrm{dL}$ and a target $\mathrm{Hb}$ range of $11-12 \mathrm{~g} / \mathrm{dL}$ in relatively young active patients. ${ }^{6}$ In the USA, the majority $(66 \%)$ of hemodialysis patients had mean $\mathrm{Hb}$ levels in the range of $10-12 \mathrm{~g} / \mathrm{dL},{ }^{10}$ although the concept of a target $\mathrm{Hb}$ range had been removed. ${ }^{11}$ However, maintaining $\mathrm{Hb}$ values continuously within a narrow target range has been described as difficult. ${ }^{12,13}$ 
Thus, there have been many attempts to create anemia management algorithms for hemodialysis patients. ${ }^{14-22}$ Nevertheless, there is no generally accepted algorithm. ${ }^{14}$ A majority of algorithms do not consider the length of erythrocyte lifetimes ${ }^{23}$ and mainly focus on ESA management without considering the combination of ESA management and iron administration. To appropriately manage the ESA dose, we believe that an anemia management algorithm should consider the length of erythrocyte lifetimes and focus on the combination of ESA management and iron administration. Further, we believe that an anemia management algorithm should prevent not only iron deficiency but also iron overload. Thus, we created an algorithm that addressed these issues and evaluated its control of $\mathrm{Hb}$ values and iron indices.

\section{Materials and methods}

\section{Study design}

The study population was drawn from 88 hemodialysis patients at the Yokkaichi Social Insurance Hospital (this hospital name was changed to Yokkaichi Hazu Medical Center in April 2014). The exclusion criteria included patients with chronic hepatitis, patients whose principal physicians wanted to control any anemia by themselves, hospital patients, patients who did not receive ESAs, patients who received continuous erythropoietin receptor activator, patients who declined consent, and patients who had started hemodialysis within the past 6 months (Figure 1). Therefore, we introduced

\section{In all, 88 hemodialysis patients were available for} participation in our study

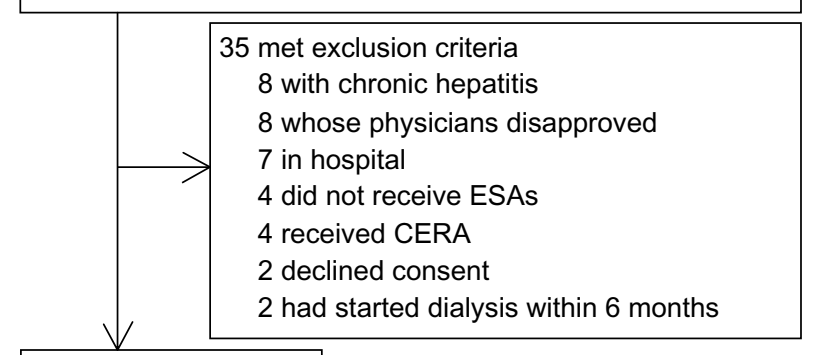

53 patients enrolled

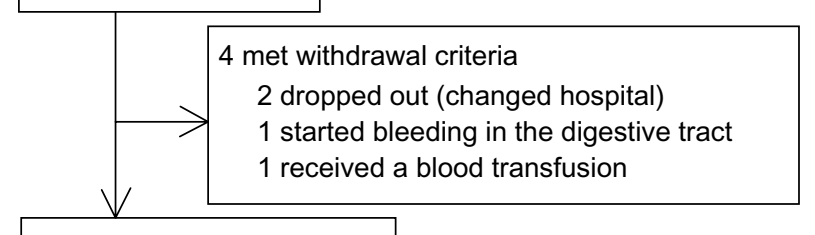

49 patients were analyzed

Figure I The flow of patients.

Abbreviations: ESA, erythropoiesis-stimulating agent; CERA, continuous erythropoietin receptor activator. our anemia management algorithm to 53 patients from May 2013 to November 2013 and evaluated how our algorithm could control $\mathrm{Hb}$ values and iron indices.

Withdrawal criteria included patients whose $\mathrm{Hb}$ values decreased to $\geq 1.5 \mathrm{~g} / \mathrm{dL}$ from the last $\mathrm{Hb}$ results because of hemorrhage, patients who needed a blood transfusion, patients who dropped out from our algorithm because of a change in hospitals, and patients who died.

Our study was approved by the ethics committee of the Yokkaichi Social Insurance Hospital (now known as Yokkaichi Hazu Medical Center). All participating patients signed informed consent forms.

\section{Blood test schedule}

Blood tests were performed at the beginning of the first dialysis of the week, which had the longest interval from the last dialysis. At a regular blood test, which was a monthly blood test, $\mathrm{Hb}$, serum iron, total iron-binding capacity, and albumin were measured. At an intermediate blood test, which was taken between two consecutive regular blood tests, $\mathrm{Hb}$ was measured (Figure 2). Ferritin was measured once every three regular blood tests or at 0,3 , and 6 months after we introduced our algorithm. The transferrin saturation rate (TSAT) was calculated from serum iron and total iron-binding capacity $(\mathrm{TSAT}=100 \times$ serum iron/total ironbinding capacity).

\section{Anemia management algorithm}

Our anemia management algorithm comprised an iron algorithm and an ESA algorithm. Our algorithm established a target $\mathrm{Hb}$ range of $10-12 \mathrm{~g} / \mathrm{dL}$. All decisions in our algorithm were evaluated by physicians. If a decision was approved by physicians, it was reflected in the treatment.

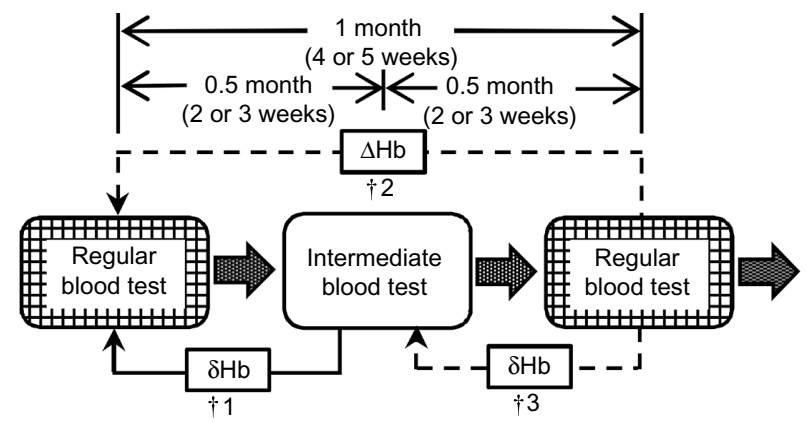

Figure 2 Blood test schedule.

Notes: ${ }^{\dagger}$. During an intermediate blood test, the hemoglobin $(\mathrm{Hb})$ change for 0.5 month $(\delta \mathrm{Hb})$ was evaluated. ${ }^{2}$. During a regular blood test, if the erythropoiesisstimulating agent dose was not changed at the last intermediate blood test, the $\mathrm{Hb}$ change for I month $(\Delta \mathrm{Hb})$ was evaluated. ${ }^{\dagger 3}$. During a regular blood test, if the erythropoiesis-stimulating agent dose was changed at the last intermediate blood test, the $\mathrm{Hb}$ change for 0.5 month $(\delta \mathrm{Hb})$ was evaluated. 


\section{Iron algorithm}

To prevent iron deficiency, the iron algorithm made decisions regarding iron administration at every regular blood test (Figure 3). If ferritin was not measured during a month, the last ferritin result was used. If iron administration was selected, the patient received intravenous administration of saccharated ferric oxide $\left(\right.$ Fesin $^{\circledR}$; Nichi-iko Pharmaceutical Co, Ltd, Toyama, Japan) of $40 \mathrm{mg}$ per week for 4 weeks, which was defined as one course. Criteria for TSAT and ferritin were compliant with the Japanese Society for Dialysis Therapy Anemia Guidelines. ${ }^{6}$

\section{ESA algorithm}

The ESA algorithm comprised the processes shown in Figures 4-12. First, the flow chart in Figure 4 divided a case into six charts (Chart numbers 1-6; Figures 5-10). Second, according to $\mathrm{Hb}$ values and $\mathrm{Hb}$ changes, each chart then divided the case into seven conditions (Conditions $A-G$ ). Third, using the decision table (Figure 11), the algorithm selected a treatment according to the state of iron administration. If an ESA dose was going to be changed, the dose per week was either increased or decreased step by step according to Figure 12.

Additionally, we created a special condition to prevent the stagnation of low $\mathrm{Hb}$ values. When the $\mathrm{Hb}$ value remained $<10 \mathrm{~g} / \mathrm{dL}$ despite the last ESA increase 3 months ago and the $\mathrm{Hb}$ increase for the last 3 months remained $\leq 0.5 \mathrm{~g} / \mathrm{dL}$, our ESA algorithm would elect to increase the ESA dose unconditionally (Figure 8).

In our study, epoetin beta (EPOGIN ${ }^{\circledR}$; Chugai Pharmaceutical Co, Ltd, Tokyo, Japan) and darbepoetin alpha (NESP ${ }^{\circledR}$; Kyowa Hakko Kirin Co, Ltd, Tokyo, Japan) were used intravenously. The dose conversion ratio between epoetin beta and darbepoetin alpha was 225:1 in our ESA algorithm. Thus, doses of epoetin beta of 2,250, 4,500, and 9,000 IU were interchangeable with doses of darbepoetin alpha of 10, 20, and $40 \mu \mathrm{g}$, respectively, in our ESA algorithm (Figure 12). After the ESA dose per week was determined, epoetin beta was mainly administered at each dialysis session, and darbepoetin alpha was administered once a week.

\section{The way to use our algorithm in our study}

Because our algorithm became somewhat complicated, we designed a program that could quickly make decisions based on our anemia management algorithm using Microsoft Office Excel $^{\circledR} 2007$ (Microsoft Corporation, Redmond, WA, USA); we used the program to make decisions in our study.

\section{Statistical analysis}

For comparisons between baseline data and data at the end of our study, the paired $t$-test was used. For comparisons of the $\mathrm{Hb}$ standard deviation between baseline and other time points after we introduced our algorithm, the $F$-test

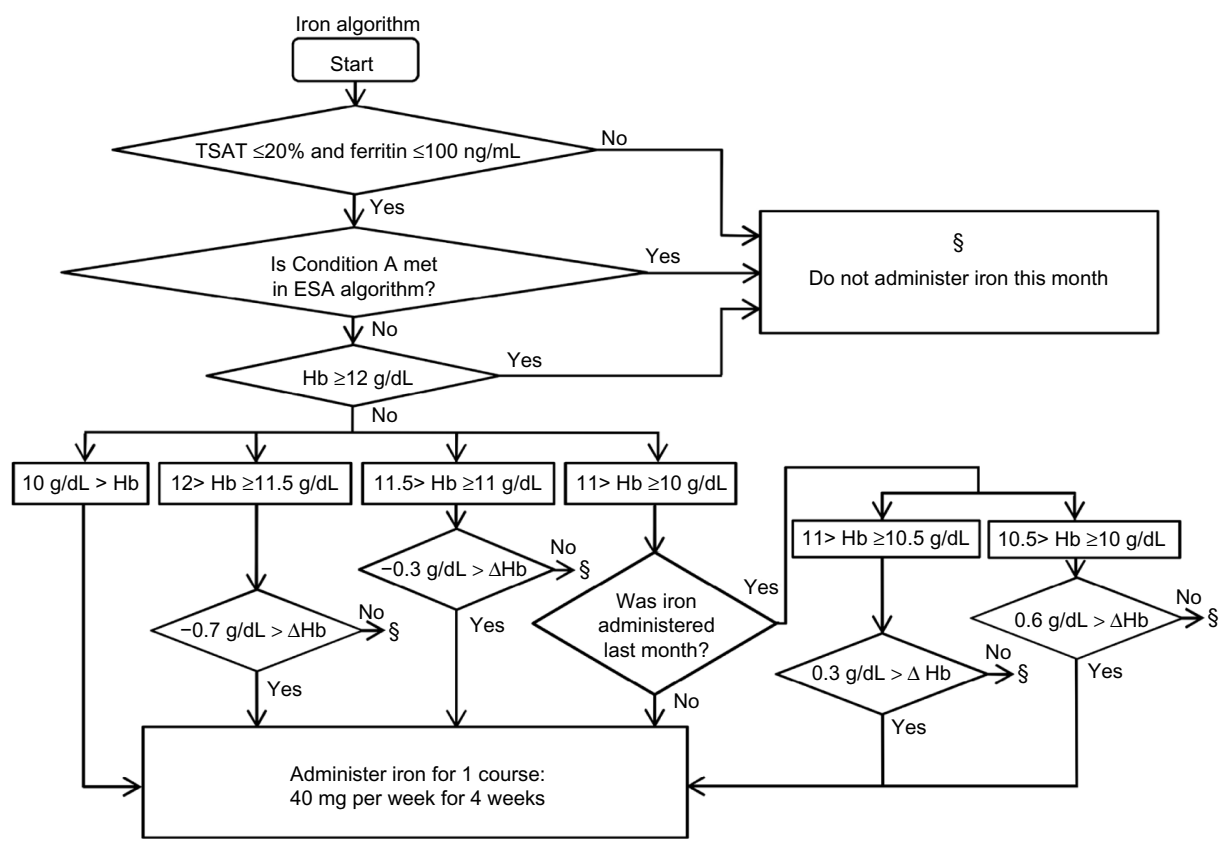

Figure 3 Iron algorithm.

Notes: This algorithm was used only at regular blood tests. If ferritin was not measured during a month, the last ferritin result was used. ${ }^{\S}$ Do not administer iron this month. Abbreviations: $\mathrm{Hb}$, hemoglobin $(\mathrm{g} / \mathrm{dL}) ; \Delta \mathrm{Hb}$ : $\mathrm{Hb}$ changes for I month $(\mathrm{g} / \mathrm{dL})$ : $\mathrm{ESA}$, erythropoiesis-stimulating agent. 


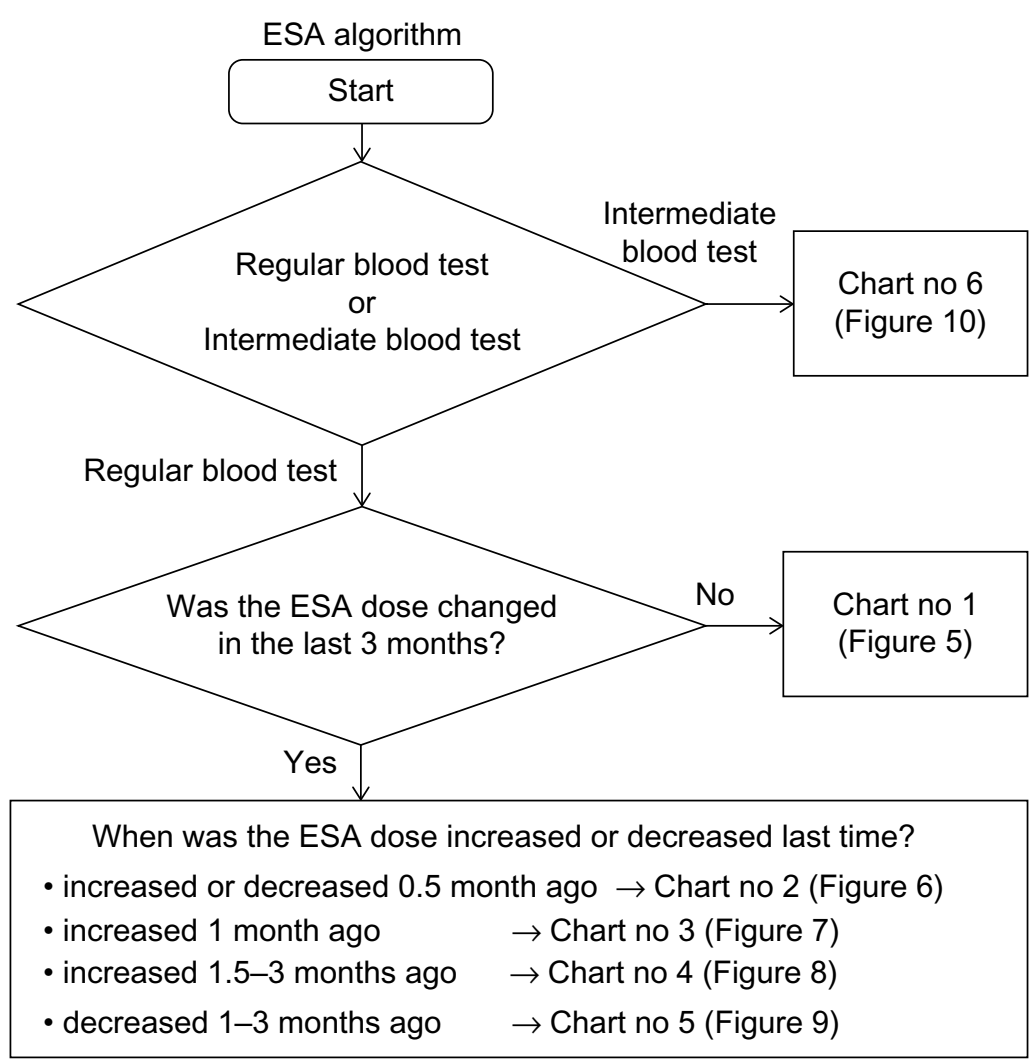

Figure 4 First flow chart of erythropoiesis-stimulating agent (ESA) algorithm.

for two population variances with correlated observations was used. ${ }^{24}$ All data were analyzed using Microsoft Office Excel $^{\circledR}$ 2007. Differences were considered significant at $P$-values of $<0.05$.

\section{Results}

We enrolled 53 hemodialysis patients initially, but four patients dropped out during our study period: two patients who dropped out from our algorithm because of changing hospitals, one patient whose $\mathrm{Hb}$ values decreased to $\geq 1.5 \mathrm{~g} /$ $\mathrm{dL}$ because of bleeding in the digestive tract, and one patient who needed a blood transfusion (Figure 1). No enrolled patient died during our study period. Therefore, in total, we analyzed 49 patients (Table 1). In addition, one patient refused to have blood drawn at every intermediate blood test, but our algorithm successfully managed the patient's anemia

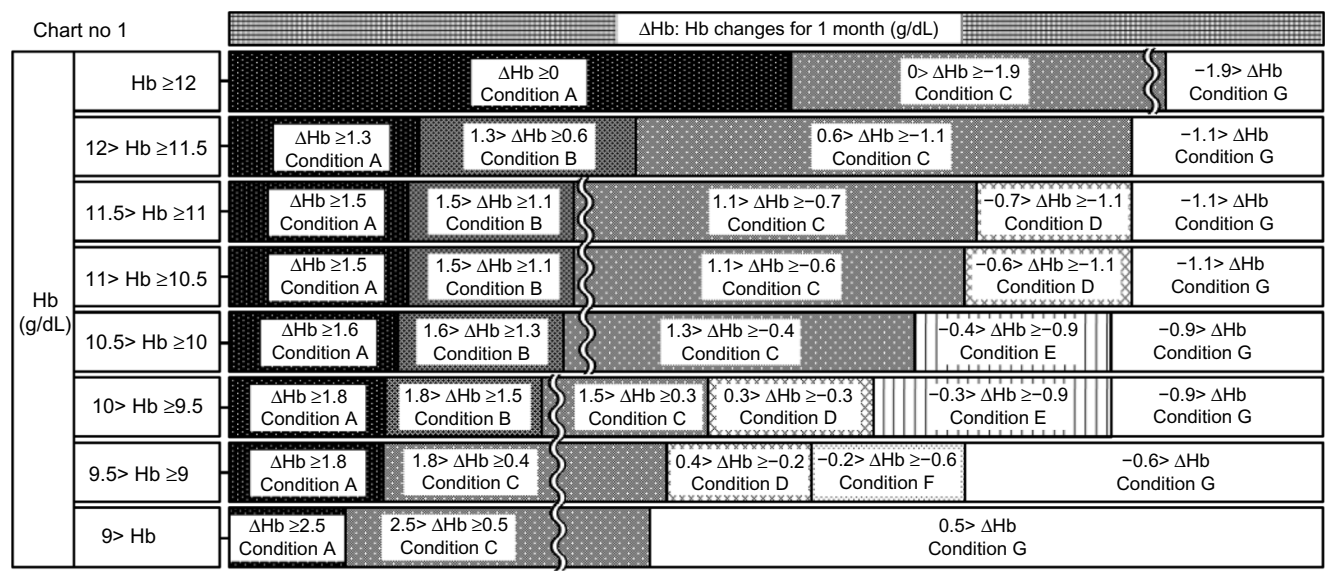

Figure 5 Chart number I: The erythropoiesis-stimulating agent dose had not been changed for the last 3 months. Each chart (Chart nos I-6; Figures 5-I0) was more sensitive to hemoglobin $(\mathrm{Hb})$ decreases than to $\mathrm{Hb}$ increases except when the $\mathrm{Hb}$ value was high, because other than deficiency of erythropoiesis-stimulating agent doses and iron, there may have been myriad causes that led to decreases in $\mathrm{Hb}$ values. 


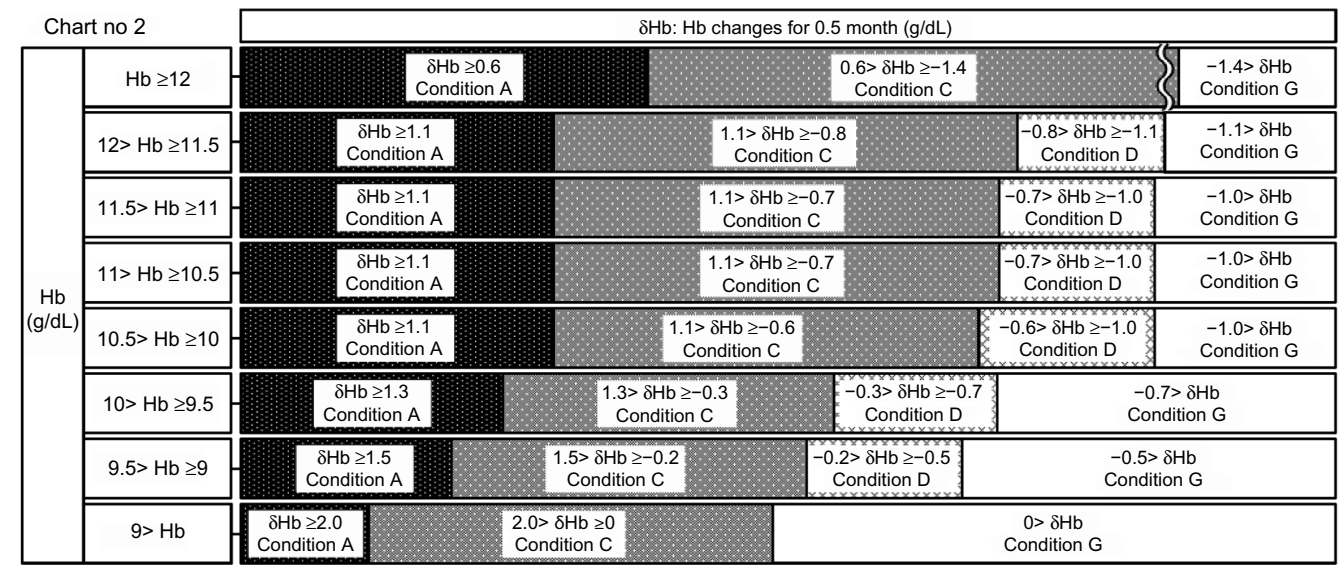

Figure 6 Chart number 2: The erythropoiesis-stimulating agent dose was increased or decreased 0.5 month ago. This chart was used to monitor hemoglobin ( $\mathrm{Hb}$ ) changes at the 0.5 -month mark and was created for monitoring short-term $\mathrm{Hb}$ increases or decreases.

according to results of regular blood tests. Therefore, for analytical use, we used data from regular blood tests because it contained complete data for these 49 patients. Moreover, although blood tests should be performed at the first dialysis of the week, which had the longest interval from the last dialysis, one patient did have blood drawn 2 days after the last dialysis once during 0 month and another patient did the same thing once during 1 month; however, no negative effect in their anemia control was recognized.

Regarding 49 analyzed patients, eleven had entered hospital during our study period: two for examination, two with infection, two with heart failure, two with bone fracture, one for parathyroidectomy, one for percutaneous peripheral intervention, and one with vertigo. No patient had myocardial or cerebral infarction.

In our study period, all decisions about our anemia management algorithm were approved by physicians. Each ESA was administered without fail. There were 34 ESA increases and 26 ESA decreases at regular blood tests $(n=49)$, and seven ESA increases and six ESA decreases at intermediate blood tests $(n=48)$. In contrast, there were 59 courses of iron administration (one course is $40 \mathrm{mg} /$ week for 4 weeks). The amount of administered iron during our study period ranged from 0 to $800 \mathrm{mg}$, and the mean dose of iron during our study period was $193 \pm 179 \mathrm{mg}$. Using our iron algorithm, we decided not to administer iron 235 times, 149 times of which TSAT was $>20 \%$.

Mean $\mathrm{Hb}$ values were approximately $11 \mathrm{~g} / \mathrm{dL}$ during our study period (Figure 13). The percentage of patients in the target $\mathrm{Hb}$ range of $10-12 \mathrm{~g} / \mathrm{dL}$ increased from $77.6 \%$ (38 of 49) at baseline to $85.7 \%$ (42 of 49) at 4-6 months (Figure 14). Throughout regular blood tests during $1-6$ months, $\mathrm{Hb}$ values remained within the target range in $55.1 \%$ ( 27 of 49 ) of patients. No patient had $\mathrm{Hb}$ values exceeding $12 \mathrm{~g} / \mathrm{dL}$ continuously

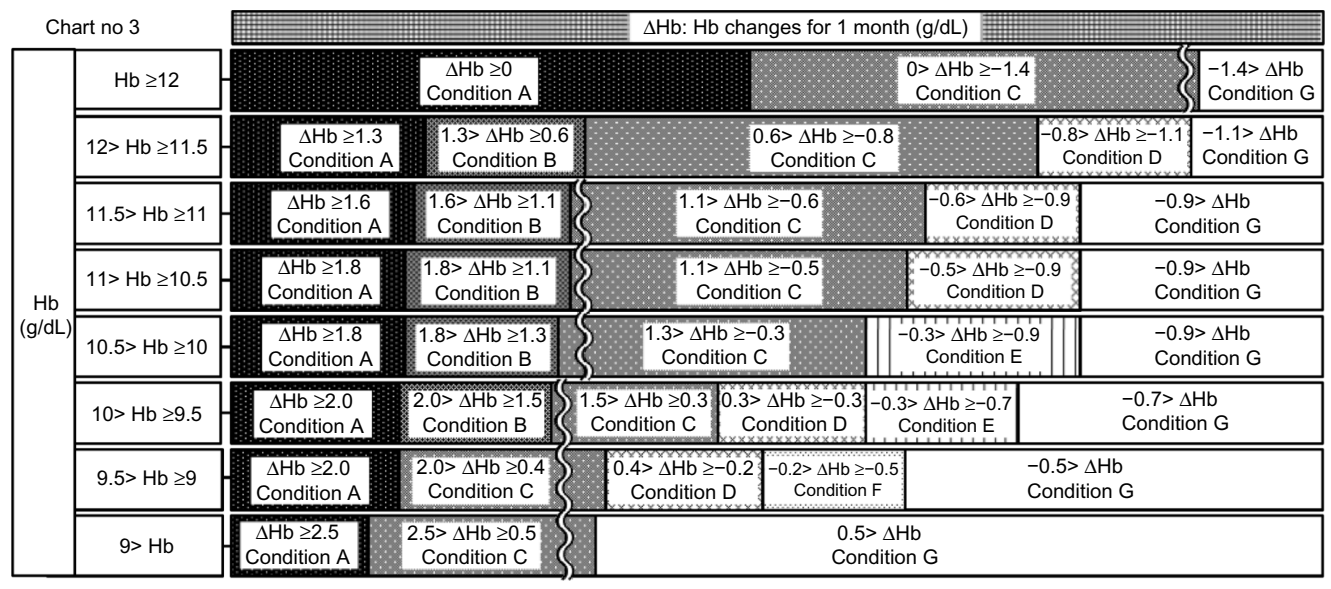

Figure 7 Chart number 3: The erythropoiesis-stimulating agent (ESA) dose was increased I month ago. Compared with Chart number I (Figure 5), this chart was more sensitive to hemoglobin $(\mathrm{Hb})$ decreases when the $\mathrm{Hb}$ value was $\geq 9 \mathrm{~g} / \mathrm{dL}$ and more permissive to $\mathrm{Hb}$ increases when $\mathrm{Hb}$ values ranged from $\geq 9$ to $<\mathrm{II} .5 \mathrm{~g} / \mathrm{dL}$, because the $\mathrm{Hb}$ value may increase partially because of an increase in ESA; however, our ESA algorithm could watch for unexpected $\mathrm{Hb}$ decreases. 


\begin{tabular}{|c|c|c|c|c|c|c|c|c|}
\hline \multicolumn{2}{|c|}{ Chart no 4} & \multicolumn{7}{|c|}{$\Delta \mathrm{Hb}: \mathrm{Hb}$ changes for 1 month $(\mathrm{g} / \mathrm{dL})$} \\
\hline \multirow{8}{*}{$\begin{array}{c}\mathrm{Hb} \\
(\mathrm{g} / \mathrm{dL})\end{array}$} & $\mathrm{Hb} \geq 12$ & & $\begin{array}{c}\Delta \mathrm{Hb} \geq 0 \\
\text { Condition A }\end{array}$ & & & $\begin{array}{c}0>\Delta \mathrm{Hb} \geq-1.4 \\
\text { Condition } \mathrm{C}\end{array}$ & & $\begin{array}{l}-1.4>\Delta \mathrm{Hb} \\
\text { Condition G }\end{array}$ \\
\hline & $12>\mathrm{Hb} \geq 11.5$ & $\begin{array}{c}\Delta \mathrm{Hb} \geq 1.3 \\
\text { Condition } \mathrm{A}\end{array}$ & $\begin{array}{l}1.3>\Delta \mathrm{Hb} \geq 0 . \\
\text { Condition B }\end{array}$ & 6 & $\begin{array}{r}0.6>\Delta \mathrm{Hb} \geq-0 \\
\text { Condition } C\end{array}$ & & $-0.8>\Delta \mathrm{Hb} \geq-1.1$ & $\begin{array}{l}-1.1>\Delta \mathrm{Hb} \\
\text { Condition G }\end{array}$ \\
\hline & $11.5>\mathrm{Hb} \geq 11$ & $\begin{array}{c}\Delta \mathrm{Hb} \geq 1.6 \\
\text { Condition } \mathrm{A}\end{array}$ & $\begin{array}{c}1.6>\Delta \mathrm{Hb} \geq 1.1 \\
\text { Condition } \mathrm{B}\end{array}$ & $\int$ & $\begin{array}{c}1.1>\Delta \mathrm{Hb} \geq-0.6 \\
\text { Condition } \mathrm{C}\end{array}$ & & $\begin{array}{c}-0.6>\Delta \mathrm{Hb} \geq-0.9 \\
\text { Condition } \mathrm{D}\end{array}$ & $\begin{array}{l}-0.9>\Delta \mathrm{Hb} \\
\text { Condition G }\end{array}$ \\
\hline & $11>\mathrm{Hb} \geq 10.5$ & $\begin{array}{c}\Delta \mathrm{Hb} \geq 1.8 \\
\text { Condition } \mathrm{A}\end{array}$ & $\begin{array}{c}1.8>\Delta \mathrm{Hb} \geq 1.1 \\
\text { Condition } \mathrm{B}\end{array}$ & a $S$ & $\begin{array}{l}1>\Delta \mathrm{Hb} \geq-0.5 \\
\text { Condition } \mathrm{C}\end{array}$ & $\begin{array}{c}-0.5>\Delta \mathrm{Hb} \geq-0.8 \\
\text { Condition } \mathrm{D}\end{array}$ & & $\begin{array}{l}0.8>\Delta \mathrm{Hb} \\
\text { ondition } \mathrm{G}\end{array}$ \\
\hline & $10.5>\mathrm{Hb} \geq 10$ & $\begin{array}{c}\Delta \mathrm{Hb} \geq 1.8 \\
\text { Condition } \mathrm{A}\end{array}$ & $\begin{array}{l}1.8>\Delta \mathrm{Hb} \geq 1.3 \\
\text { Condition } \mathrm{B}\end{array}$ & $1.3>$ & $\begin{array}{l}\Delta \mathrm{Hb} \geq-0.3 \\
\text { ondition } \mathrm{C}\end{array}$ & $\begin{array}{c}-0.3>\Delta \mathrm{Hb} \geq-0.7 \\
\text { Condition } \mathrm{E}\end{array}$ & & $\begin{array}{l}.7>\Delta \mathrm{Hb} \\
\text { ndition } \mathrm{G}\end{array}$ \\
\hline & $10>\mathrm{Hb} \geq 9.5$ & $\begin{array}{c}\Delta \mathrm{Hb} \geq 2.0 \\
\text { Condition A }\end{array}$ & $\begin{array}{c}2.0>\Delta \mathrm{Hb} \geq 1.5 \\
\text { Condition } \mathrm{B}\end{array}$ & $\begin{array}{c}1.5>\Delta \mathrm{Hb} \geq 0.4 \\
\text { Condition } C\end{array}$ & $\begin{array}{c}0.4>\Delta \mathrm{Hb} \geq-0.2 \\
\text { Condition } \mathrm{D}\end{array}$ & $\begin{array}{c}-0.2>\Delta \mathrm{Hb} \geq-0.6 \\
\text { Condition } \mathrm{E}\end{array}$ & $\begin{array}{l}-0.6 \\
\text { Con }\end{array}$ & $\begin{array}{l}6>\Delta \mathrm{Hb} \\
\text { ndition } \mathrm{G}\end{array}$ \\
\hline & $9.5>\mathrm{Hb} \geq 9$ & $\begin{array}{c}\Delta \mathrm{Hb} \geq 2.0 \\
\text { Condition } \mathrm{A}\end{array}$ & $\begin{array}{c}2.0>\Delta \mathrm{Hb} \geq 0.5 \\
\text { Condition } C\end{array}$ & $\begin{array}{l}0.5>\Delta \mathrm{Hb} \geq \\
\text { Condition }\end{array}$ & \begin{tabular}{l|l}
0 & $0>\Delta \mathrm{Hb} \geq-0.4$ \\
$D$ & Condition F
\end{tabular} & & $\begin{array}{l}-0.4>\Delta \\
\text { Conditic }\end{array}$ & $\begin{array}{l}\mathrm{AHb} \\
\text { on G }\end{array}$ \\
\hline & $9>\mathrm{Hb}$ & $\begin{array}{c}\Delta \mathrm{Hb} \geq 2.5 \\
\text { Condition } \mathrm{A}\end{array}$ & $\begin{array}{c}2.5>\Delta \mathrm{Hb} \geq 0.5 \\
\text { Condition } \mathrm{C}\end{array}$ & & & $\begin{array}{l}0.5>\Delta \mathrm{Hb} \\
\text { Condition G }\end{array}$ & & \\
\hline
\end{tabular}

Figure 8 Chart number 4: The erythropoiesis-stimulating agent (ESA) dose was increased 1.5-3 months ago. Compared with Chart number 3 (Figure 7), this chart was more sensitive to hemoglobin $(\mathrm{Hb})$ decreases when $\mathrm{Hb}$ values ranged from $\geq 9$ to $<\mathrm{II} \mathrm{g} / \mathrm{dL}$ because the Hb value should increase fully because of an increase in ESA. Our ESA algorithm could watch for unexpected $\mathrm{Hb}$ decreases.

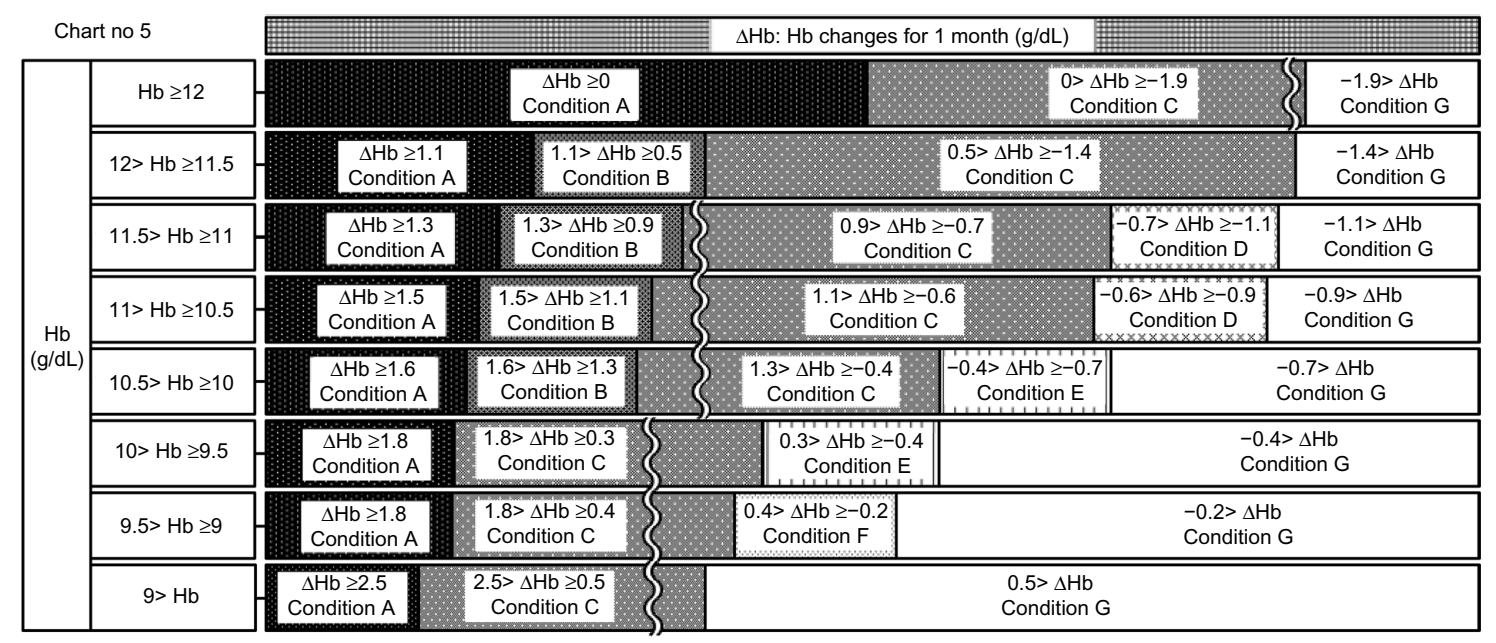

Figure 9 Chart number 5: The erythropoiesis-stimulating agent (ESA) dose was decreased I-3 months ago. Compared with Chart number I (Figure 5), this chart was more sensitive to hemoglobin $(\mathrm{Hb})$ increases when $\mathrm{Hb}$ values ranged from $\geq 1 \mathrm{I}$ to $<12 \mathrm{~g} / \mathrm{dL}$, more sensitive to $\mathrm{Hb}$ decreases when $\mathrm{Hb}$ values ranged from $\geq 9$ to $<\mathrm{II} \mathrm{g} / \mathrm{dL}$, and more permissive to $\mathrm{Hb}$ decreases when $\mathrm{Hb}$ values ranged from $\geq 1 \mathrm{I} .5$ to $<12 \mathrm{~g} / \mathrm{dL}$, because the $\mathrm{Hb}$ value should decrease because of a decrease in ESA. Our ESA algorithm could watch for unexpected $\mathrm{Hb}$ increases and excessive $\mathrm{Hb}$ decreases.

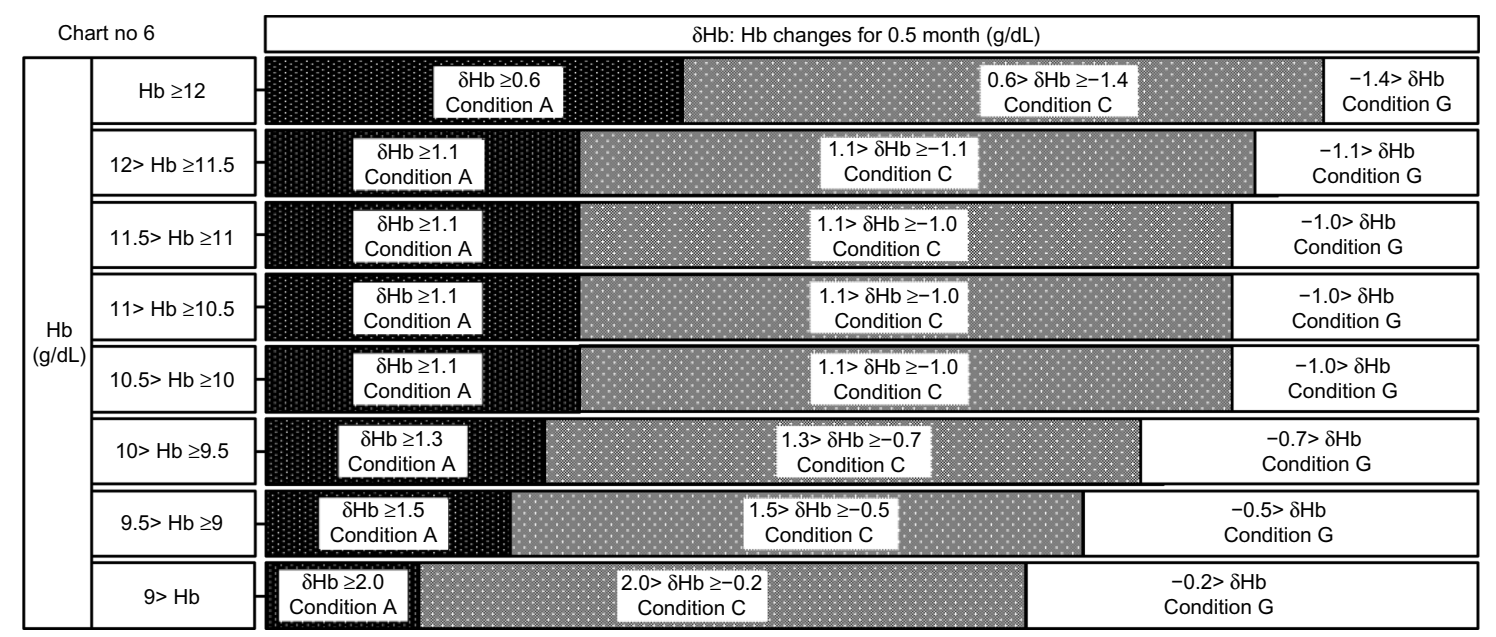

Figure 10 Chart number 6: Intermediate blood tests. This chart was used to monitor hemoglobin $(\mathrm{Hb})$ changes at the 0.5 -month mark and was created for monitoring short-term $\mathrm{Hb}$ increases or decreases. 


\begin{tabular}{|c|c|c|c|c|c|c|}
\hline Condition A & \multicolumn{6}{|c|}{ Decrease the ESA dose } \\
\hline \multirow{3}{*}{ Condition B } & \multirow{2}{*}{ - B-1: If } & Month before last & \multicolumn{2}{|c|}{ Last month } & \multirow{2}{*}{$\begin{array}{c}\text { This month } \\
\text { No iron }\end{array}$} & \multirow{3}{*}{ Do not change the ESA dose } \\
\hline & & \multicolumn{3}{|c|}{ Iron received for at least 1 month } & & \\
\hline & \multicolumn{5}{|c|}{ - B-2: Different from B-1, decrease the ESA dose } & \\
\hline Condition C & \multicolumn{5}{|c|}{ Do not change the ESA dose } & \\
\hline 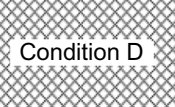 & \multicolumn{6}{|c|}{$\begin{array}{l}\cdot \mathrm{D}-1 \text { : Iron received this month } \\
\text {-D-2: No iron this month }\end{array}$} \\
\hline \multirow{4}{*}{ Condition E } & \multicolumn{5}{|c|}{ - E-1: No iron this month } & \multirow{4}{*}{ Increase the ESA dose } \\
\hline & \multirow{2}{*}{$\cdot E-2$ : If } & Month before last & Last month & & month & \\
\hline & & Iron received & Iron received & Iron & eceived & \\
\hline & \multicolumn{5}{|c|}{ - E-3: Different from E-1 or E-2, do not change the ESA dose } & \\
\hline \multirow{3}{*}{ Condition $F$} & \multirow{2}{*}{ - F-1: If } & Month before last & Last month & & month & \multirow{3}{*}{ Do not change the ESA dose } \\
\hline & & No iron & No iron & Iron & eceived & \\
\hline & \multicolumn{5}{|c|}{ - F-2: Different from F-1, increase the ESA dose } & \\
\hline Condition G & \multicolumn{6}{|c|}{ Increase the ESA dose } \\
\hline
\end{tabular}

Figure II Decision table.

Notes: "Iron received" meant that one course of iron is/was administered. "No iron" meant that iron is/was not administered.

Abbreviation: ESA, erythropoiesis-stimulating agent.

during our study period. The $\mathrm{Hb}$ standard deviation decreased over time and also decreased significantly at 5 and 6 months ( $P=0.013$ and $P=0.047$, respectively: $1 \mathrm{~g} / \mathrm{dL}$ at 0 month, $0.7 \mathrm{~g} / \mathrm{dL}$ at 5 months, and $0.7 \mathrm{~g} / \mathrm{dL}$ at 6 months; Figure 14$)$ compared with the values at baseline. There were no significant differences in ESA doses and $\mathrm{Hb}$ values between baseline data and data at the end of study ( $P=0.357$ and $P=0.682$, respectively; Table 2), but there was a significant decrease in ferritin values ( $P=0.011$; Table 2 ). Regarding 15 patients who received high doses of epoetin beta ( $\geq 9,000 \mathrm{IU})$ or darbepoetin alpha $(\geq 40 \mu \mathrm{g}$ ) at 0 month, their ESA doses did not significantly change at 6 months $(P=0.625 ; 14,100 \pm 6,721 \mathrm{IU}$ at 0 months and $14,850 \pm 10,339 \mathrm{IU}$ at 6 months. Doses of darbepoetin alpha were converted to doses of epoetin beta according to the conversion ratio of 225:1).

\section{Discussion}

Our anemia management algorithm, which comprised an iron algorithm (Figure 3) and an ESA algorithm (Figures 4-12), succeeded in controlling $\mathrm{Hb}$ values and iron indices in the following ways. First, our algorithm increased the number of patients in the target $\mathrm{Hb}$ range of 10-12 $\mathrm{g} / \mathrm{dL}$ (Figure 14). Second, our algorithm significantly decreased the $\mathrm{Hb}$ standard deviation (Figure 14). We believe that the increase in the number of patients in the target $\mathrm{Hb}$ range was associated with the stability of mean $\mathrm{Hb}$ values at approximately $11 \mathrm{~g} / \mathrm{dL}$ (Figure 13) and the decrease in the $\mathrm{Hb}$ standard deviation (Figures 13 and 14). Third, our iron algorithm suppressed cumulative doses of iron and significantly decreased ferritin values (Table 2).

These results imply a better prognosis for hemodialysis patients. First, the increase in the numbers of patients in the

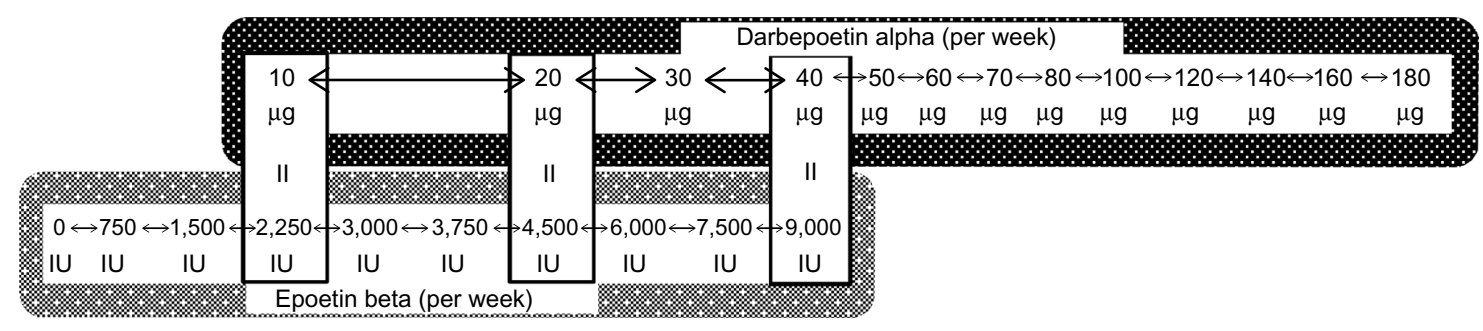

Figure 12 Erythropoiesis-stimulating agent dose adjustment worksheet. Note: $=$, interchangeable. 
Table I Baseline characteristics

\begin{tabular}{ll}
\hline & $\mathbf{n = 4 9}$ \\
\hline Age (years) & $67.1 \pm 10.4$ \\
Female (n) & 24 \\
Diabetes mellitus (n) & 19 \\
Duration of HD (months) & $124 \pm 105$ \\
\hline
\end{tabular}

Note: Age and duration of $\mathrm{HD}$ are presented as mean \pm standard deviation. Abbreviation: HD, hemodialysis.

target $\mathrm{Hb}$ range implies better outcomes. Maintaining $\mathrm{Hb}$ values within a certain range is important because too high or too low $\mathrm{Hb}$ values have been shown to worsen prognosis. ${ }^{48}$ The Japanese Society for Dialysis Therapy reported that the 5 -year survival rate of hemodialysis patients was best in the $\mathrm{Hb}$ range of $10-11 \mathrm{~g} / \mathrm{dL}$; in young hemodialysis patients, that was best in the $\mathrm{Hb}$ range of $11-12 \mathrm{~g} / \mathrm{dL} .^{6}$ Therefore, because the target $\mathrm{Hb}$ range of $10-12 \mathrm{~g} / \mathrm{dL}$ in our study was associated with an improved prognosis, the increase in the number of patients within this range implies a better prognosis overall.

Second, the decrease in the amount of the $\mathrm{Hb}$ standard deviation suggests better outcomes. Pisoni et al had reported that the facility-level $\mathrm{Hb}$ standard deviation was strongly and positively associated with mortality. ${ }^{25}$ Although further investigations are required for evaluating whether this result can be applied to a patient, Pisoni et al had also reported that facility-level $\mathrm{Hb}$ standard deviation was strongly associated with within-patient $\mathrm{Hb}$ variability, ${ }^{25}$ which had been reported to be positively associated with mortality. ${ }^{26}$ Therefore, a decrease in the $\mathrm{Hb}$ standard deviation may indicate a better prognosis.

Finally, suppressing cumulative doses of iron and decreasing ferritin values also possibly led to better outcomes. Kuo et al had reported that a cumulative intravenous iron dose of $>800 \mathrm{mg}$ for 6 months significantly increased risks of

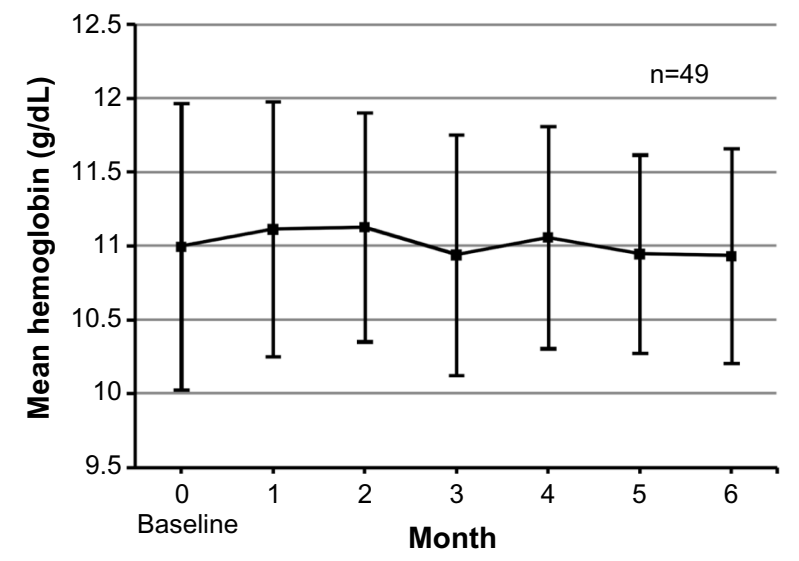

Figure 13 Trend in mean hemoglobin values \pm standard deviation at regular blood tests. cardiovascular events and overall mortality in hemodialysis patients. ${ }^{27}$ To this, our iron algorithm prevented excessive iron administration in patients with high $\mathrm{Hb}$ values and suppressed consecutive iron administration when $\mathrm{Hb}$ values ranged from $\geq 10$ to $<11 \mathrm{~g} / \mathrm{dL}$ (Figure 3 ). Consequently, no patient received a cumulative intravenous iron dose of $>800$ mg during our 6-month study period, suggesting a better prognosis. In addition, our iron algorithm also decreased ferritin values. Hasuike et al had reported that the high ferritin group ( $\geq 100 \mathrm{ng} / \mathrm{mL}$; median ferritin, $161.9 \mathrm{ng} / \mathrm{mL}$ ) was associated with a poor prognosis compared with the low ferritin group $(<100 \mathrm{ng} / \mathrm{mL}$; median ferritin, $37 \mathrm{ng} /$ $\mathrm{mL}),{ }^{28}$ whose ferritin values were similar to those at the end of our study (Table 2). Therefore, decreased ferritin values also suggest a better prognosis. In contrast, we think that our algorithm also succeeded in preventing iron deficiency because there were no significant differences in ESA doses and $\mathrm{Hb}$ values between baseline data and data at the end of study (Table 2).

There have been many anemia management algorithms for hemodialysis patients. ${ }^{14-22}$ Kalicki and Uehlinger have argued that algorithms should take into account all information that includes at least one erythrocyte lifetime. ${ }^{23}$ Using this concept, Lines et al reported about a predictive algorithm that considered the length of erythrocyte lifetimes and predicted $\mathrm{Hb}$ values at 90 days after the last ESA dose change. ${ }^{21}$ However, we believe that their algorithm did not consider any short-term $\mathrm{Hb}$ changes and thus lost the flexibility to adapt to unexpected occurrences. In contrast, several algorithms incorporating iron indices have been reported, ${ }^{14,17,19-21}$ but we think that even with these algorithms, the combination of ESA management and iron administration was insufficient.

Our ESA algorithm incorporated two mechanisms that would lead to appropriate ESA management. One mechanism acknowledged the importance of the length of erythrocyte lifetimes, and the other incorporated the combination of ESA management and iron administration. Our successful anemia management was based on these two mechanisms.

By incorporating the mechanism related to the length of erythrocyte lifetimes, our ESA algorithm became particularly sensitive or permissive to $\mathrm{Hb}$ changes that were associated with recent ESA dose changes. Kalicki and Uehlinger also have argued that the time needed to achieve a steady state for hematocrit values after an increase in the ESA dose is equal to one erythrocyte lifetime, ${ }^{23}$ which is approximately 60-90 days..$^{29,30}$ Thus, our algorithm broadly classified ESA dose changes into the following cases: cases after a recent ESA increase (Chart numbers 3 and 4), a case after a recent 


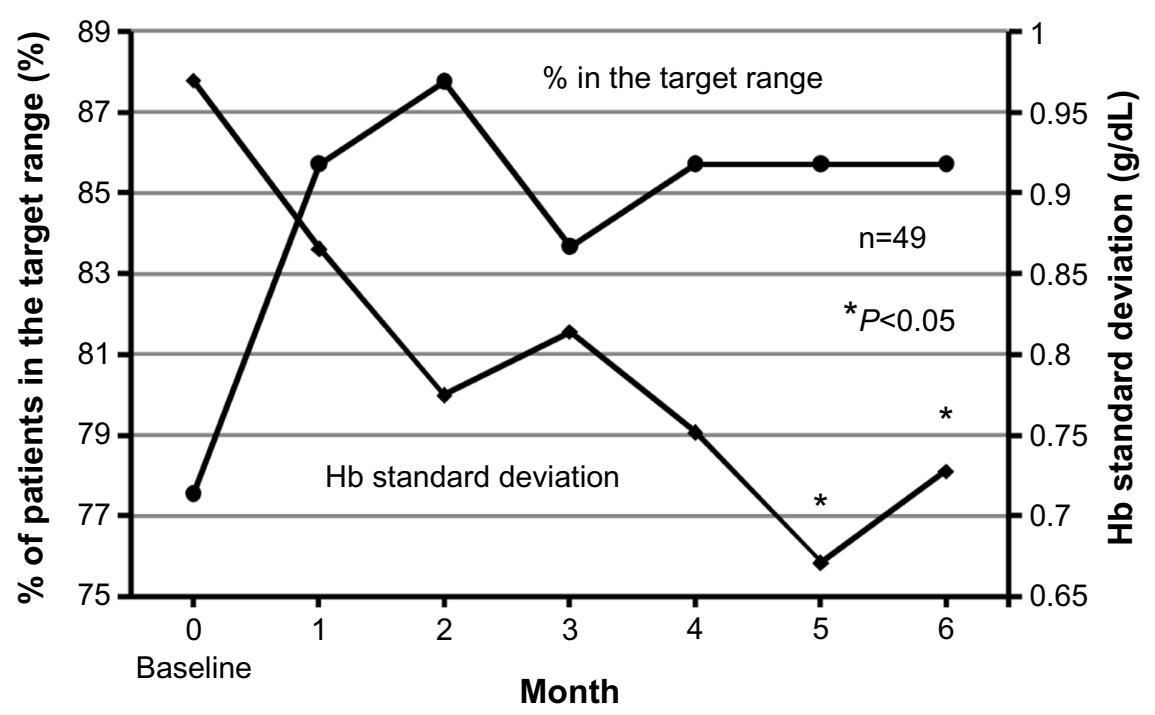

Figure 14 Percentage of patients in the target hemoglobin $(\mathrm{Hb})$ range of $10-12 \mathrm{~g} / \mathrm{dL}$ and the trend in the $\mathrm{Hb}$ standard deviation at regular blood tests.

ESA decrease (Chart number 5), and a case in a steady state (Chart number 1). Because of these classifications, our algorithm became sensitive or permissive to $\mathrm{Hb}$ changes so that our algorithm could appropriately manage the ESA doses. Moreover, Mizuguchi has argued that after an ESA dose change, it takes more than 1 week before there is a change in $\mathrm{Hb}$ values because an erythroid colony-forming unit, which ESA acts on, will need 1 week to develop into an erythrocyte. ${ }^{31}$ Because of this delay in the $\mathrm{Hb}$ reaction, the $\mathrm{Hb}$ change at 1 month after an ESA increase will be relatively insufficient. Therefore, we made the chart at 1 month after the ESA increase (Chart number 3; Figure 7) more permissive to $\mathrm{Hb}$ decreases than the chart at 1.5-3 months after the ESA increase (Chart number 4; Figure 8). In contrast, we regarded a delay in the $\mathrm{Hb}$ reaction to an ESA decrease as ignorable because other than ESA decreases, there may have been myriad causes that led to decreases in Hb values. ${ }^{21}$

Table 2 Comparisons between baseline data ( 0 month) and data at the end of our study (6 months)

\begin{tabular}{llll}
\hline & $\begin{array}{l}\mathbf{0} \text { month } \\
(\mathbf{n = 4 9 )}\end{array}$ & $\begin{array}{l}\mathbf{6} \text { months } \\
(\mathbf{n = 4 9 )}\end{array}$ & P-value \\
\hline Hemoglobin $(\mathrm{g} / \mathrm{dL})$ & $\mathrm{II} \pm \mathrm{I}$ & $10.9 \pm 0.7$ & 0.682 \\
ESA dose $\left(\mathrm{IU} /\right.$ week) $^{\mathrm{a}}$ & $7,133 \pm 6,107$ & $7,592 \pm 7,759$ & 0.357 \\
Cardiothoracic ratio $(\%)$ & $50.4 \pm 5.2$ & $49.8 \pm 5.3$ & 0.226 \\
Dry weight $(\mathrm{kg})$ & $54 \pm \mathrm{II} .3$ & $53.6 \pm \mathrm{II} .4$ & $0.18 \mathrm{I}$ \\
Albumin $(\mathrm{g} / \mathrm{dL})$ & $3.6 \pm 0.4$ & $3.6 \pm 0.3$ & 0.325 \\
TSAT $(\%)$ & $21.5 \pm 7.3$ & $20.6 \pm 7$ & 0.409 \\
Ferritin $(\mathrm{ng} / \mathrm{mL})$ & $50.7 \pm 39.2$ & $37.4 \pm 27.2$ & $0.01 \mathrm{I}$ \\
\hline
\end{tabular}

Notes: Data are presented as mean \pm standard deviation. ${ }^{a}$ Doses of darbepoetin alpha were converted to doses of epoetin beta according to the conversion ratio of 225:I. Abbreviations: ESA, erythropoiesis-stimulating agent; TSAT, transferrin saturation rate.
Next, by incorporating the mechanism for the combination of ESA management and iron administration, we were able to use our ESA algorithm to appropriately manage ESA doses depending on the state of recent iron administration. In general, $\mathrm{Hb}$ values increase after iron administration ${ }^{32}$ and decrease in iron deficiency. ${ }^{33}$ However, if Hb changes attributed to the iron status had been incorrectly categorized as $\mathrm{Hb}$ changes because of an excess or a deficiency in ESA doses, unnecessary ESA dose changes may be made and a stable control of $\mathrm{Hb}$ values will be difficult to achieve. Therefore, our ESA algorithm incorporated the management of ESA doses according to the state of iron administration for preventing unnecessary ESA dose changes. This combination mechanism was integrated in Conditions B and D-F.

Condition $\mathrm{B}$ was created for preventing unnecessary ESA decreases. With Condition $\mathrm{B}$, when $\mathrm{Hb}$ values increased after recent iron administration without subsequent iron administration later, our ESA algorithm did not decrease ESA doses because this increase was probably due to iron administration and was probably transient. Nakanishi et al had estimated that if the $\mathrm{Hb}$ value increased by $0.2-0.3 \mathrm{~g} / \mathrm{dL}, 30-50 \mathrm{mg}$ of the intravenous iron had been used for erythropoiesis. ${ }^{34}$ With this information, after $160 \mathrm{mg}$ of intravenous iron (one course in our study) was administered, the $\mathrm{Hb}$ value may increase by $0.6-1.6 \mathrm{~g} / \mathrm{dL}$; this range was similar to that in Condition B (Figures 5 and 7-9). Thus, our ESA algorithm distinguished $\mathrm{Hb}$ increases after recent iron administration from $\mathrm{Hb}$ increases that were probably due to excessive ESA doses and prevented unnecessary ESA decreases.

Conversely, Conditions D-F were created for preventing unnecessary ESA increases. For Conditions D-F, if $\mathrm{Hb}$ 
values were stagnated or decreased because of insufficient iron administration and iron could be administered later, our ESA algorithm did not increase ESA doses because these $\mathrm{Hb}$ changes were likely due to iron deficiency. By doing so, our ESA algorithm prevented unnecessary ESA increases. However, for preventing additional $\mathrm{Hb}$ decreases, decisions to increase ESA doses were easier with Conditions $\mathrm{E}$ and $\mathrm{F}$ than with Condition D. Using Condition E, if iron had been administered for 3 consecutive months, our algorithm increased ESA doses because the $\mathrm{Hb}$ reaction to iron administration was poor (Figure 11). Using Condition F, our algorithm increased ESA doses unless there was a plan to administer iron hereafter; if there had been no recent iron administration, the $\mathrm{Hb}$ reaction to iron administration may still be good (Figure 11).

Our study has several limitations. First, our study evaluated a small sample size during a relatively short period, and it was not a randomized control trial. Although we indicated the possibility of our algorithm for a better prognosis, to evaluate whether our algorithm actually improves the prognosis of hemodialysis patients, we would require a larger sample size during a longer period. Additional studies will be required to evaluate our algorithm.

Second, the benefit from maintaining $\mathrm{Hb}$ values continuously within the target range remains unknown as it has been described as difficult and has been rarely achieved. ${ }^{12,13}$ For 6 months, we succeeded in maintaining $\mathrm{Hb}$ values continuously within the target range of $10-12 \mathrm{~g} / \mathrm{dL}$ in more than half of the patients. Using our algorithm, the benefit from maintaining $\mathrm{Hb}$ values continuously may become clear.

Third, because our algorithm became somewhat complicated, a software program may be useful for supporting hemodialysis practices. Therefore, we designed and used such a program in our study.

\section{Conclusion}

Our anemia management algorithm successfully increased the number of patients in the target $\mathrm{Hb}$ range of $10-12 \mathrm{~g} / \mathrm{dL}$, significantly decreased the $\mathrm{Hb}$ standard deviation, suppressed cumulative doses of iron, and decreased ferritin values. These results suggest a better prognosis for hemodialysis patients.

\section{Acknowledgment}

The authors sincerely appreciate the advice and comments from Daijo Inaguma.

\section{Author contributions}

All authors have contributed to the study. Kazuhiro Hara, Yasuhide Mizutani, Hitoshi Kodera, and Masato Miyake were the physicians in charge of patient care (including monitoring of $\mathrm{Hb}$ values), and they evaluated decisions made according to our anemia management algorithm. Yoshiki Yasuda and Sanae Ohara, clinical engineers, were in charge of supervising the implementation of our anemia management algorithm. Moreover, Yoshiki Yasuda and Sanae Ohara also contributed to the appropriate operation of the program that quickly made decisions based on our algorithm using Microsoft Office Excel ${ }^{\circledR}$ 2007. All coauthors contributed equally to the critical revisions of this manuscript.

\section{Disclosure}

The authors report no conflicts of interest in this work.

\section{References}

1. Eschbach JW, Egrie JC, Downing MR, Browne JK, Adamson JW. Correction of the anemia of end-stage renal disease with recombinant human erythropoietin. Results of a combined phase I and II clinical trial. N Engl J Med. 1987;316(2):73-78.

2. Eschbach JW, Abdulhadi MH, Browne JK, et al. Recombinant human erythropoietin in anemic patients with end-stage renal disease. Results of a phase III multicenter clinical trial. Ann Intern Med. 1989;111(12): 992-1000.

3. Eschbach JW, Kelly MR, Haley NR, Abels RI, Adamson JW. Treatment of the anemia of progressive renal failure with recombinant human erythropoietin. N Engl J Med. 1989;321(3):158-163.

4. Ma JZ, Ebben J, Xia H, Collins AJ. Hematocrit level and associated mortality in hemodialysis patients. J Am Soc Nephrol. 1999;10(3): 610-619.

5. Locatelli F, Pisoni RL, Combe C, et al. Anaemia in haemodialysis patients of five European countries: association with morbidity and mortality in the Dialysis Outcomes and Practice Patterns Study (DOPPS). Nephrol Dial Transplant. 2004;19(1):121-132.

6. Tsubakihara Y, Nishi S, Akiba T, et al. 2008 Japanese Society for Dialysis Therapy: guidelines for renal anemia in chronic kidney disease. Ther Apher Dial. 2010;14(3):240-275.

7. Besarab A, Bolton WK, Browne JK, et al. The effects of normal as compared with low hematocrit values in patients with cardiac disease who are receiving hemodialysis and epoetin. $N$ Engl J Med. 1998;339(9): 584-590.

8. Cotter DJ, Stefanik K, Zhang Y, Thamer M. Improved survival with higher hematocrits: where is the evidence? Semin Dial. 2004;17(3): 181-183.

9. Locatelli F, Bárány P, Covic A, et al. Kidney disease: improving global outcomes guidelines on anaemia management in chronic kidney disease: a European Renal Best Practice position statement. Nephrol Dial Transplant. 2013;28(6):1346-1359.

10. USRDS.org [homepage on the Internet]. Bethesda, MD: National Institutes of Health, National Institute of Diabetes and Digestive and Kidney Diseases; 2014. Available from: http://www.usrds.org/adr.aspx. Accessed March 29, 2015.

11. FDA.gov [homepage on the Internet]. Rockville, MD: The US Food and Drug Administration; 2011. Available from: http://www.fda.gov/ Drugs/DrugSafety/ucm259639.htm. Accessed March 29, 2015.

12. Portolés JM, de Francisco AL, Górriz JL, et al. Maintenance of target hemoglobin level in stable hemodialysis patients constitutes a theoretical task: a historical prospective study. Kidney Int. 2008;74(111): S82-S87.

13. Ebben JP, Gilbertson DT, Foley RN, Collins AJ. Hemoglobin level variability: associations with comorbidity, intercurrent events, and hospitalizations. Clin J Am Soc Nephrol. 2006;1(6):1205-1210. 
14. Thakuria M, Ofsthun NJ, Mullon C, Diaz-Buxo JA. Anemia management in patients receiving chronic hemodialysis. Semin Dial. 2011; 24(5):597-602.

15. Brier ME, Gaweda AE, Dailey A, Aronoff GR, Jacobs AA. Randomized trial of model predictive control for improved anemia management. Clin J Am Soc Nephrol. 2010;5(5):814-820.

16. Gaweda AE, Aronoff GR, Jacobs AA, Rai SN, Brier ME. Individualized anemia management reduces hemoglobin variability in hemodialysis patients. J Am Soc Nephrol. 2014;25(1):159-166.

17. Brimble KS, Rabbat CG, McKenna P, Lambert K, Carlisle EJ. Protocolized anemia management with erythropoietin in hemodialysis patients: a randomized controlled trial. JAm Soc Nephrol. 2003;14(10): 2654-2661.

18. Ho WR, Germain MJ, Garb J, et al. Use of $12 \times /$ month haemoglobin monitoring with a computer algorithm reduces haemoglobin variability. Nephrol Dial Transplant. 2010;25(8):2710-2714.

19. Murakami K, Suzuki T, Uchino J, et al. The influence that renal anemia management in the low ferritin $(<60 \mathrm{ng} / \mathrm{mL})$ gives to an anemiarelated various factors. Kidney and Dialysis. 2013;74(3):463-467 [in Japanese].

20. Patterson P, Allon M. Prospective evaluation of an anemia treatment algorithm in hemodialysis patients. Am J Kidney Dis. 1998;32(4): 635-641.

21. Lines SW, Lindley EJ, Tattersall JE, Wright MJ. A predictive algorithm for the management of anaemia in haemodialysis patients based on ESA pharmacodynamics: better results for less work. Nephrol Dial Transplant. 2012;27(6):2425-2429.

22. Miskulin DC, Weiner DE, Tighiouart H, et al. Computerized decision support for EPO dosing in hemodialysis patients. Am J Kidney Dis. 2009;54(6):1081-1088.

23. Kalicki RM, Uehlinger DE. Red cell survival in relation to changes in the hematocrit: more important than you think. Blood Purif. 2008;26(4): 355-360.

24. Kanji GK. Test 17 F-Test for Two Population Variances (with Correlated Observations), in 100 Statistical Tests. 3rd ed. London, UK: Sage; 2006:46-47.

25. Pisoni RL, Bragg-Gresham JL, Fuller DS, et al. Facility-level interpatient hemoglobin variability in hemodialysis centers participating in the Dialysis Outcomes and Practice Patterns Study (DOPPS): associations with mortality, patient characteristics, and facility practices. Am J Kidney Dis. 2011;57(2):266-275.
26. Yang W, Israni RK, Brunelli SM, Joffe MM, Fishbane S, Feldman HI. Hemoglobin variability and mortality in ESRD. J Am Soc Nephrol. 2007;18(12):3164-3170.

27. Kuo KL, Hung SC, Lin YP, et al. Intravenous ferric chloride hexahydrate supplementation induced endothelial dysfunction and increased cardiovascular risk among hemodialysis patients. PLOS ONE. 2012;7(12):e50295. doi: 10.1371/journal.pone.0050295. Available from: http://journals.plos.org/plosone/article?id=10.1371/journal. pone.0050295. Accessed March 29, 2015.

28. Hasuike Y, Nonoguchi H, Tokuyama M, et al. Serum ferritin predicts prognosis in hemodialysis patients: the Nishinomiya study. Clin Exp Nephrol. 2010;14(4):349-355.

29. Vos FE, Schollum JB, Coulter CV, Doyle TC, Duffull SB, Walker RJ. Red blood cell survival in long-term dialysis patients. Am J Kidney Dis. 2011;58(4):591-598.

30. Sato Y, Mizuguchi T, Shigenaga S, et al. Shortened red blood cell lifespan is related to the dose of erythropoiesis-stimulating agents requirement in patients on hemodialysis. Ther Apher Dial. 2012;16(6):522-528.

31. Mizuguchi T. Dosing regimens of erythropoiesis-stimulating agents in hemodialysis patients in terms of bone marrow hematopoiesis. Kidney and Dialysis. 2013;75(1):125-132 [in Japanese].

32. Coyne DW, Kapoian T, Suki W, et al. Ferric gluconate is highly efficacious in anemic hemodialysis patients with high serum ferritin and low transferrin saturation: results of the Dialysis Patients' Response to IV Iron with Elevated Ferritin (DRIVE) Study. J Am Soc Nephrol. 2007;18(3):975-984.

33. Chung M, Chan JA, Moorthy D, et al. [Investigators]. Biomarkers for assessing and managing iron deficiency anemia in late-stage chronic kidney disease: future research needs: identification of future research needs from comparative effectiveness review no 83. Future Research Needs Papers. Rockville, the United States: Agency for Healthcare Research and Quality; 2013 Jan. Report No: 13-EHC038-EF. Available from: http://www.ncbi.nlm.nih.gov/books/NBK143610/. Accessed March 29, 2015.

34. Nakanishi T, Hasuike Y, Nagasawa Y, Kuragano T. How much intravenous iron is utilized for erythropoiesis? Am J Med. 2013;126(11):e27. doi: 10.1016/j.amjmed.2013.05.028. Available from: http://www. amjmed.com/article/S0002-9343\%2813\%2900733-X/fulltext. Accessed March 29, 2015.

\section{Publish your work in this journal}

The International Journal of Nephrology and Renovascular Disease is an international, peer-reviewed open-access journal focusing on the pathophysiology of the kidney and vascular supply. Epidemiology, screening, diagnosis, and treatment interventions are covered as well as basic science, biochemical and immunological studies. The journal welcomes

\section{Dovepress}

original research, clinical studies, reviews \& evaluations, expert opinion and commentary, case reports and extended reports. The manuscript management system is completely online and includes a very quick and fair peerreview system, which is all easy to use. Visit http://www.dovepress.com/ testimonials.php to read real quotes from published authors 